\title{
PENGARUH KONSUMSI AIR PUTIH TERHADAP HASIL PEMERIKSAAN KRISTAL OKSALAT DALAM URIN PADA PASIEN RAWAT JALAN DI PUSKESMAS PAGESANGAN
}

\author{
Baiq Dhea, Erna Kristinawati, Fitria Ernawati \\ Jurusan Analis Kesehatan, Poltekkes Kemenkes Mataram, Indonesia.
}

\begin{tabular}{l} 
Article Info \\
Article history: \\
Received Jan $23^{\text {th }}, 2019$ \\
Revised Feb $1^{\text {th }}, 2019$ \\
Accepted Feb $13^{\text {th }}, 2019$ \\
\hline
\end{tabular}

Keyword:

Water

Oxalate Crystal

Urine.

\begin{abstract}
Calcium oxalate is a crystal like sharp needles that implant themselves in the tissue and can cause extreme pain. One way to prevent the formation of calcium oxalate crystals is by consuming lots of water. The main function of water in the body is as a solvent, so that water becomes an easy and suitable medium to transport nutrients to the body's cells and to remove metabolic waste. This study was to determine the effect of consumption of water on the results of examination of oxalate crystals in urine in outpatients at Pagesangan Health Center. This study was a Pre-Experimental study with the design of the One Group Pretest Posttest. The sample in this study amounted to 15 people. Urine samples in outpatients with urine sediment examination revealed oxalate crystals in the urine. Then respondents were given 2 liters of water / day and had to be consumed for seven days. Then calcium oxalate crystals were examined after treatment. Data analysis to determine the effect of consumption of water on the results of examination of oxalate crystals in urine in outpatients in the clinic health center used statistical tests using the Wilcoxon Rank Test non parametric test. The statistical test results show a probability value of $0,000<\alpha=$ 0.05 , which means that there is an effect of giving water to the results of examination of oxalate crystals in urine in outpatients at the public health center. There is an effect of giving water to the results of examination of oxalate crystals in urine in outpatients at Pagesangan Health Center.
\end{abstract}

Keywords: Water, Oxalate Crystal, Urine.

Copyright (C) JurnalAnalisMedika Bio Sains All rights reserved. 


\begin{abstract}
ABSTRAK
Kalsium oksalat berupa kristal seperti jarum-jarum tajam yang menanamkan diri dalam jaringan dan dapat menyebabkan sakit luar biasa. Salah satu cara untuk mencegah pembentukan kristal kalsium oksalat yaitu dengan banyak mengkonsumsi air putih. Fungsi utama air di dalam tubuh adalah sebagai pelarut, sehingga air menjadi medium yang mudah dan cocok untuk mengangkut zat gizi ke sel-sel tubuh dan untuk membuang sisa metabolisme. Penelitian ini adalah untuk mengetahui adanya pengaruh konsumsi air putih terhadap hasil pemeriksaan Kristal oksalat dalam urin pada pasien rawat jalan di Puskesmas Pagesangan.

Penelitian ini merupakan penelitian Pra Eksperimen dengan rancangan One Group Pretest Posttest. Sampel dalam penelitian ini berjumlah 15 orang. Sampel urin pada pasien rawat jalan dengan hasil pemeriksaan sedimen urin menunjukkan adanya Kristal oksalat dalam urin. Kemudian responden diberikan air putih sebanyak 2 liter/hari dan harus dikonsumsi selama tujuh hari. Lalu dilakukan pemeriksaan Kristal kalsium oksalat setelah perlakuan. Analisis data untuk mengetahui adanya pengaruh konsumsi air putih terhadap hasil pemeriksaan kristal oksalat dalam urin pada pasien rawat jalan di puskesmas pagesangan digunakan uji statistik menggunakan uji non parametrik Wilcoxon Rank Test. Hasil uji statistic menunjukkan nilai probabilitas $0,000<\alpha=0,05$ artinya ada pengaruh pemberian air putih terhadap hasil pemeriksaan Kristal oksalat dalam urin pada pasien rawat jalan di puskesmas pagesangan. Ada pengaruh pemberian air putih terhadap hasil pemeriksaan Kristal oksalat dalam urin pada pasien rawat jalan di Puskesmas Pagesangan.
\end{abstract}

\title{
Kata Kunci :Air Putih, Kristal oksalat, Urin.
}




\section{Pendahuluan}

Pemeriksaan sedimen urin merupakan salah satu dari pemeriksaan urin rutin. Pengetahuan mengenai adanya suatu unsur dalam sedimen urin secara mikroskopis tidak boleh diabaikan, contohnya Kristal kalsium oksalat. $^{1}$

Kalsium oksalat berupa kristal seperti jarum-jarum tajam yang menanamkan diri dalam jaringan dan dapat menyebabkan sakit luar biasa. Kalsium oksalat dapat menyebabkan sekitar 80 persen penyakit batu ginjal pada orang dewasa. Oksalat dapat mengendapkan kalsium dan membentuk kalsium oksalat yang tidak dapat diserap oleh tubuh, sehingga terbentuk endapan garam yang tidak larut yang menyebabkan munculnya penyakit batu ginjal. Di dalam tubuh, oksalat akan bersenyawa dengan kalsium membentuk kristal kalsium oksalat. Kristal tersebut akan mengendap dan jika terkumpul akan membesar membentuk batu ginjal. Batu ginjal terbentuk akibat ginjal yang kekurangan cairan untuk memecahkan kelebihan mineral seperti oksalat, kalsium atau asam urat dari makanan. ${ }^{2}$

Salah satu cara untuk mencegah pembentukan Kristal kalsium oksalat yaitu dengan banyak mengkonsumsi air putih. Fungsi utama air di dalam tubuh adalah sebagai pelarut, sehingga air menjadi medium yang mudah dan cocok untuk mengangkut zat gizi ke sel-sel tubuh dan untuk membuang sisa metabolisme. $^{3}$

Pembentukan kristal kalsium oksalat berlangsung lama, bahkan tahunan. Ukurannya kecil- kecil sehingga saat minum banyak air putih, batu-batu yang berukuran kecil tersebut bisa keluar saat buang air kecil dengan sendirinya bila berukuran dibawah $1 \mathrm{~cm}$, umumnya 6 mm. Santoso dkk. (2011) menyebutkan, bagi orang dewasa, pengeluaran urin 2 liter sehari dapat melarutkan berbagai sisa metabolisme melalui urin dan pembuangannya dengan lancar. Guna menghasilkan urin paling tidak 2 liter sehari maka setiap orang perlu minum lebih dari 2 liter sehari tergantung suhu lingkungan, aktivitas serta jumlah dan jenis makanan. Kondisi tubuh akan menurun bila kadar air tubuh menurun dan kita tidak segera memenuhi kecukupan air tersebut. Untuk itu, dianjurkan agar mengonsumsi setidaknya 2 liter air putih sehari sehingga jumlah urin yang dikeluarkan akan bertambah dan mengurangi konsentrasi garam serta mineral dalam tubuh. Oleh karena itu, air berperan penting dalam mencegah penyakit ginjal dalam hal mengurangi kemungkinan timbulnya Kristal oksalat dalam saluran kemih.

Akan tetapi, tanpa disadari asupan cairan yang lebih banyak dikonsumsi oleh sebagian besar masyarakat adalah minuman seperti teh, kopi, atau jus yang ternyata mengandung agen dehidrasi sehingga sangat penting untuk memahami dengan benar cairan yang baik. Kurangnya pemahaman tentang pentingnya kebiasaan minum air putih di kalangan masyarakat inilah, maka perlu salah satu cara yang tepat untuk dapat memberikan informasi tentang kebiasaan air putih dengan harapan agar memberikan pengetahuan kepada subjek 
terhadap pentingnya kebiasaan minum air

putih. $^{4}$ Oleh karena itu, penelitian ini bertujuan

untuk menegetahui pengaruh konsumsi air putih terhadap hasil pemeriksaan kristal oksalat dalam urin pada pasien rawat jalan di Puskesmas Pagesangan.

\section{Metode Penelitian}

Penelitian ini merupakan penelitian Pra Eksperimen (Pre Experimental Design) yaitu suatu penelitian dengan melakukan kegiatan percobaan (experiment), yang bertujuan untuk mengetahui pengaruh konsumsi air putih terhadap hasil pemeriksaan kristal oksalat dalam urin pada pasien rawat jalan di puskesmas pagesangan. Pengumpulan data dan pengujian laboratorium dalam penelitian ini dilaksanakan pada bulan April hingga bulan Mei 2019 Rancangan penelitian yang digunakan adalah One Group Pretest Posttest. Rancangan ini tidak ada kelompok pembanding (kontrol), tetapi paling tidak telah dilakukan observasi pertama (pretest) yang memungkinkan menguji perubahan-perubahan yang terjadi setelah adanya eksperimen (program). ${ }^{5}$

Teknik pengambilan sampel yang digunakan dalam penelitian ini adalah Non Random Purposive Sampling yaitu penelitian yang didasarkan pada suatu pertimbangan tertentu yang dibuat oleh peneliti sendiri, berdasarkan ciri atau sifat-sifat populasi yang sudah diketahui sebelumnya (Notoatmojo, 2012). Adapun sampel yang digunakan dalam penelitian, yaitu memenuhi kriteria inklusi dan ekslusi. Terdapat tiga kriteria inklusi sampel penelitian yakni pasien rawat jalan dengan hasil pemeriksaan sedimen urin menunjukkan adanya kristal oksalat dalam urin, mengkonsumsi air putih kurang dari 2 liter per hari dan bersedia menjadi responden dengan menandatangani informed concent.Adapun sampel yang masuk dalam kriteria inklusi berdasarkan perhitungan dengan rumus Faderer sebanyak 15 sampel. Variabel dalam penelitian ini terdiri dari variable bebas yaitu konsumsi air putih, sedangkan variable terikat yaitu kristal oksalat dalam urin.

Data dari hasil penelitian pemeriksaan kalsium oksalat dalam urin sebelum dan setelah pemberian air putih sebanyak 2 liter per hari pada pasien rawat jalan di Puskesmas Pagesangan pada masing-masing sampel dianalisis statistik menggunakan uji non parametric Wilcoxon Rank Test dengan tingkat kepercayaan 95\% ( $p \alpha=0,05)$. Kriteria pembacaan hasil uji statistic Wilcoxon Rank Test adalah apabila probabilitas $<\alpha 0,05$ maka $\mathrm{H}_{0}$ ditolak $\mathrm{H}_{\mathrm{a}}$ diterima, artinya ada pengaruh pemberian air putih terhadap hasil pemeriksaan Kristal oksalat dalam urin pada pasien rawat jalan di Puskesmas Pagesangan. Apabila probabilitas $>\alpha 0,05 \mathrm{H}_{0}$ diterima $\mathrm{H}_{\mathrm{a}}$ ditolak, artinya tidak ada pengaruh pemberian air putih terhadap hasil pemeriksaan Kristal oksalat dalam urin pada pasien rawat jalan di Puskesmas Pagesangan. 


\section{Hasil Penelitian dan Pembahasan}

Hasil pemeriksaan Kristal oksalat Pagesangan sebelum dan setelah pemberian air terhadap 15 pasien rawat jalan di Puskesmas putih dapat dilihat pada tabel 4.1 di bawah ini.

Tabel 4.1 Hasil Pemeriksaan Kristal oksalat Sebelum dan Setelah Pemberian Air Putih Pada pasien rawat jalan di Puskesmas Pagesangan

\begin{tabular}{|c|c|c|c|c|c|}
\hline \multirow[t]{2}{*}{ No } & \multirow[t]{2}{*}{ KODE SAMPEL } & \multicolumn{2}{|c|}{ UMUR } & \multicolumn{2}{|c|}{ Hasil pemeriksaan Kristal oksalat } \\
\hline & & $\mathbf{L}$ & $\mathbf{P}$ & Sebelum & Setelah \\
\hline 1 & DI & 80 & & Positif 1 & Negatif \\
\hline 2 & $\overline{\text { IGNP }}$ & & & Positif 1 & Negatif \\
\hline 3 & NMY & & & Positif 1 & Negatif \\
\hline 4 & SR & & & Positif 1 & Negatif \\
\hline 5 & $\overline{M G}$ & & 22 & Positif 2 & Positif 1 \\
\hline 6 & $\overline{\mathrm{LS}}$ & & 24 & Positif 1 & Negatif \\
\hline 7 & $\mathrm{HY}$ & 51 & & Positif 1 & Negatif \\
\hline 8 & $\overline{S Y}$ & & 55 & Positif 1 & Negatif \\
\hline 9 & $\overline{\mathrm{AY}}$ & & 55 & Positif 1 & Negatif \\
\hline 10 & $\overline{\mathrm{NW}}$ & & 22 & Positif 1 & Negatif \\
\hline 11 & BNI & & 21 & Positif 1 & Positif 1 \\
\hline 12 & $\overline{\mathrm{MSY}}$ & & 21 & Positif 2 & Negatif \\
\hline 13 & SDH & & 22 & Positif 1 & Negatif \\
\hline 14 & MT & 23 & & Positif 1 & Negatif \\
\hline 15 & SK & 22 & & Positif 1 & Negatif \\
\hline
\end{tabular}

Berdasarkan tabel 4.1 menunjukkan bahwa pemeriksaan Kristal oksalat sebelum pemberian air putih, yaitu sebanyak 15 sampel terdapat Kristal oksalat dalam urin, sedangkan pemeriksaan Kristal oksalat setelah pemberian air putih, yaitu sebanyak 2 sampel masih terdapat Kristal oksalat namun jumlahnya berkurang sedangkan sebanyak 13 sampel tidak terdapat Kristal oksalat dalam urin. Hal ini disebabkan karena pengenceran air kemih dengan banyak minum menyebabkan peningkatan koefisien ion aktif setara dengan proses kristalisasi air kemih. Dengan mengkonsumsi air putih yang banyak, maka akan mengurangi rata-rata umur Kristal oksalat yang terkandung di dalam kandung kemih dan dapat mengeluarkan komponen tersebut bersama dengan urin.

Selain itu, terdapat satu sampel sebelum perlakuan ditemukan Kristal oksalat dengan kadar positif 2 kemudian setelah perlakuan menjadi positif 1. Berdasarkan hasil wawancara mendalam dengan responden, diketahui bahwa responden sering mengkonsumsi minuman bersoda atau dalam kehidupan sehari-hari disebut dengan soft drink. Penelitian menemukan bahwa risiko munculnya Kristal oksalat dalam urin sejalan 
dengan kandungan asam fosfat dalam soft drink. Mekanisme pemunculan kristal oksalat yaitu rasio $\mathrm{Ca}: \mathrm{P}$ normal dalam tubuh adalah 2:1. Dalam kondisi rasio yang ideal ini, penyerapan terhadap kalsium menjadi optimal. Soft drink memiliki kadar fosfat yang tinggi yang menyebabkan terganggunya keseimbangan rasio $\mathrm{Ca}: \mathrm{P}$ yang berakibat pada terhambatnya penyerapan kalsium dan menyebabkan kalsium menjadi tidak terlarut sehingga kalsium mengendap di ginjal dalam bentuk Kristal kompleks. 6 Oleh karena itu, walaupun responden tersebut tetap mengkonsumsi air putih, namun minuman soft drink tersebut akan memicu kembali terbentuknya Kristal oksalat sehingga tetap terdapat Kristal oksalat dalam urin responden tersebut walaupun telah mengkonsumsi air putih sebanyak 2 liter per hari. Sedangkan pada satu sampel lainnya, sebelum perlakuan ditemukan Kristal oksalat dengan kadar positif 1 kemudian setelah perlakuan tetap positif 1 . Hal ini dikarenakan dalam penelitian ini, peneliti hanya menggunakan satu kelompok tanpa menggunakan kelompok kontrol sehingga tidak terlihat perbedaan antara kelompok yang mengkonsumsi air putih dan tidak mengkonsumsi air putih sebanyak 2 liter per hari. Selain itu, pada saat diberikan perlakuan, subjek tidak mendapatkan pengamatan langsung dari peneliti sehingga ada kemungkinan subjek tidak mengkonsumsi air putih dengan volume yang telah diberikan. ${ }^{7}$

\section{Hasil Uji Statistik}

Untuk mengetahui hasil pemeriksaan Kristal oksalat dalam urin pada pasien rawat jalan di puskesmas pagesangan, dilakukan analisis data dengan uji statistik Wilcoxon Rank Test. Adapun hasil uji Wilcoxon Rank Test dapat dilihat pada tabel 4.2.

Tabel 4.2 Hasil Uji Wilcoxon

Rank Test

\begin{tabular}{cllcl}
\hline No. & Variabel & Jumlah & P \\
\hline 1. & Sebelum & & \\
& - & Hasil Positif & 15 & \\
& - & Hasil Negatif & 0 & \\
\hline 2. & & Setelah & & \\
& - & Hasil Positif & 2 & \\
& - & Hasil Negatif & 13 &
\end{tabular}

Signifikan $\mathrm{p}<0.05$

Berdasarkan hasi $1 \quad$ uji statistik dengan metode Wilcoxon Rank Test pada tabel 4.2 di atas, hasil pemeriksaan Kristal oksalat dalm urin pada pasien rawat jalan di puskesmas pagesangan menunjukkan nilai probabilitas $0,000<\alpha=0,05$ artinya ada pengaruh konsumsi air putih terhadap hasil pemeriksaan Kristal oksalat dalam urin pada pasien rawat jalan di Puskesmas Pagesangan. Berdasarkan hasil penelitian Triyanti (2007) menunjukkan terdapat hubungan yang bermakna antara kebiasaan minum responden dengan terjadinya kristalisasi urin. Hal ini sesuai dengan penelitian Borghi, dkk (1999) yang menyatakan peningkatan volume urin terjadi karena asupan cairan yang banyak memberikan pengaruh yang menguntungkan untuk mencegahan terjadinya kristalisasi kalsium oksalat pada urin. Dia juga menyimpulkan bahwa asupan cairan yang banyak terutama air putih merupakan 
pencegahan yang paling kuat dan juga paling ekonomis terhadap terjadinya nephrolithiasis. ${ }^{8}$

Air yang masuk kedalam tubuh langsung diserap oleh usus halus dan usus besar, kemudian masuk kedalam pembuluh darah. Penelitian yang dilakukan Peronnet dkk. (2012) menunjukkan bahwa air yang diminum masuk ke dalam plasma dalam waktu 5 menit. Jika tubuh merasa kekentalan darah sudah cukup untuk menyalurkan zat-zat makanan, sisa/kelebihan air akan disalurkan ke ginjal. Setiap hari tidak kurang 180 liter cairan tubuh difiltrasi di glomerulus ginjal dan menghasilkan urine 1-2 liter. Rata-rata berkemih orang normal sebanyak 5 hingga 6 kali dengan volume kurang lebih 300 ml setiap berkemih. ${ }^{9}$

\section{Kesimpulan}

Hasil pemeriksaan sampel urin menunjukkan bahwa kadar kristal oksalat sebelum pemberian air putih yaitu sebanyak 13 sampel positif 1 dan 2 sampel positif 2 . Sedangkan setelah pemberian air putih kadar kristal oksalat yaitu sebanyak 13 sampel negatif dan 2 sampel lainnya positif 1 . Hal tersebut menunjukkan ada pengaruh pemberian air putih terhadap kadar Kristal oksalat dalam urin pada pasien rawat jalan di Puskesmas Pagesangan dengan nilai probabilitas $0,000<\alpha=0,05$.

\section{Daftar Pustaka}

1. Briawan, D., Sedayu, T. R., \& Ekayanti, I. (2011). Kebiasaan minum dan asupan cairan remaja di perkotaan, Jurnal Gizi Klinik Indonesia (260), 36-41.

2. Fitriani, H. Nurlailah. Rachmina, D.
(2016). Kandungan Asam Oksalat Sayur Bayam. Medical Laboratory Technology Journal, 2(2), 51-55.

3. Diyani, D. A. 2012. Hubungan Pengetahuan, Aktivitas Fisik dan Faktor Lain Terhadap Konsumsi Air Minum pada Mahasiswa FKM UI Tahun 2012. Skripsi. Fakultas Kesehatan Masyarakat UI, Depok.

4. Prasastia, M. (2013). Pengaruh Jumlah Kebiasaan Minum Air Putih Terhadap Hasil Pemeriksaan Sedimen Urinalisis Pada Masyarakata Pendukuhan Dayakan, Sardonoharjo Ngaglik, Sleman. Skripsi. Fakultas Farmasi Universitas Sanata Dharma.Yogyakarta

5. Notoatmojo, S. (2012). Metodologi Penelitian Kesehatan. Penerbit Rineka Cipta. Jakarta.

6. Lina, N. (2008). Faktor-faktor Resiko Kejadian Batu Saluran Kemih pada Lakilaki. Tesis. Program Pasca Sarjana Universitas Diponegoro, Semarang.

7. Yunus R \& Yuniarty T. (2016). Orang Yang Meminum Air Minum Kemasan Isi Ulang ( Air Galon ) Dan Orang Yang Meminum Air Minum Dari Sumur Gali. Jurnal of Meditory, 4(1), 1-5.

8. Pratiwi, C.D. \& Puspitasari, E. (2019). Identifikasi Sedimen Urine Pada Penduduk Yang Mengkonsumsi Air Sumur Di Desa Besole Kecamatan Besuki Kabupaten Tulungagung. Borneo Jurnal of Medical Laboratory Technology, 1(4), 1-5.

9. Purnomo, B. B. 2011.Dasar - Dasar Urologi.Edisi: 3. Jakarta: CV. Sagung Seto. 


JurnalAnalisMedika Bio Sains

Vol.x, No.x, Februari201x, pp. Xx $\sim \mathrm{xx}$

ISSN: 2656-2456 (Online)

ISSN: 2356-4075 (Print)

$\square$ 